\title{
Multitraumer og traumesentre
}

Behandling av flerorganskader og andre alvorlige traumer står sentralt i befolkningens tanker om medisinsk nytte. Forventningen er at sterkt skadede blir tatt hånd om på best mulig måte av helsepersonell på skadestedet og via den prehospitale tjeneste kommer inn under sykehusenes spesialiserte diagnostikk, behandling og rehabilitering. Også i områder av Norge med store avstander og lav befolkningstetthet forventes det at behandlingen av store skader skal være på høyt nivå.

I Nord-Norge innebærer de geografiske forhold og samfunnsstrukturen at det stilles store krav til helsetjenesten. Dehli og medarbeidere presenterer i dette nummer av Tidsskriftet pasienter med registrerte alvorlige skader overført fra lokalsykehus til Universitetssykehuset NordNorge i en toårsperiode (1). De belyser lokalsykehusenes rolle, de livreddende prosedyrers og bildediagnostikkens plass og traumesenterets oppgaver. Problemstillingen er: Hvordan kan leddene i behandlingskjeden gjøres enda bedre? Helse Nord arbeider nå med en plan for tilpasning og utbygging av traumesystemet i regionen (2).

Alvorlige traumer (injury severity score (ISS) > 15) er en tallmessig liten del av alle skader, store og små, som diagnostiseres og behandles i ulike deler av helsetjenesten. Noen enorganskader (f.eks. nevrokirurgiske skader og ansiktsskader) kan være alvorlige uten at ISS $>15$. Skadetilfeller kan oppfattes som alvorlige og kreve omfattende prehospital innsats, akuttbehandling og diagnostikk - før konklusjonen blir mindre eller ingen skade. Andre tilfeller kan initialt synes å være mer beskjedne enn de viser seg å være. De alvorlige skadene er ressurskrevende, innebærer stor risiko for invaliditet og død og setter høye krav til medisinsk teknologi, klinisk traumerelatert kompetanse, kunnskaper i flerorganskadens patofysiologi og disiplinert arbeid i team.

Norge har fire helseregioner, hver med et utbygd traumesenter (Nord - 0,46 milioner innbyggere, Midt-Norge - 0,67, Vest - 1,0, Sør-Øst - 2,7). Den minste regionen i nord har en skadeepidemiologi i samsvar med befolkningsgrunnlaget. Dehli og medarbeidere rapporterer at Universitetssykehuset Nord-Norge i 2006 og 2007 til sammen mottok akutt 74 alvorlig skadede med ISS $>15$ fra lokalsykehusene. Dette vil være en liten del av det nordnorske helsevesens totale behandlingsvolum av store og små skader. I Helse Nords egen plan oppgis at traumeteamene ved nordnorske sykehus årlig aktiveres 500-600 ganger - med ca. 130 alvorlig skadede som fasit (2). Til sammenlikning mottok traumesenteret i Helse Sør-Øst (Ullevål) i 2008 akutt direkte eller fra lokalsykehus 529 pasienter med skader med ISS $>15$. Av disse hadde 366 hodeskader, 160 columnaskader og 106 ansiktsskader (de fleste med flerorganskade).

I den landsomfattende traumesystemutredningen fra 2007 redegjøres det for hvilke funksjoner de ulike ledd i helsetjenesten bør ha (3). Et lokalsykehus som mottar pasienter med akutte, alvorlige skader, forutsettes å ha et fast definert, trent traumeteam og alltid tilgjengelig kompetanse for nødkirurgiske prosedyrer. Et traumesenter skal kunne utføre alle typer kirurgisk behandling. Det forutsettes døgnkontinuerlig røntgentjeneste med angiografi (intraarteriell embolisering og stentbehandling). Senteret gir definitiv behandling ved alle hode-, thorax- og bukskader, bruddbehandling med osteosyntese av alle typer, plastikkirurgisk behandling av bløtvevsskader, operativ behandling av alle typer spinale skader og intensivbehandling (langvarig respiratorbehandling, dialyse, intra- cerebral trykkmåling, avansert sirkulasjonsovervåking). I utredningen foreslås sentralisering på landsbasis av enkelte kategorier av skader, bl.a. pleksusskader i overekstremiteter, komplekse bekkenskader og komplekse ansiktsskader. Man vektlegger kursing av leger, sykepleiere og ambulansepersonell. Tidlig rehabilitering er en nødvendig tjeneste i traumesenteret $(3,4)$.

Traumatologisk forskning med et flerorganperspektiv vil bidra til forbedring av traumesystemet. Både Wisborg og Gaarder har vist hvor viktig opplæring er $(5,6)$. Skaga har fremlagt forslag til forbedret modell for prediksjon av overlevelse (7). I utenlandske studier har man påvist den gunstige effekten av et regionalisert traumesystem (8). Sammenfattede traumemetodebøker bidrar til kvalitet (9). Ansiktstraumatologien har fått sin metodebok (10). Metodebeskrivelser forplikter helsepersonellet og helseforetakene ved at definerte metoder fastsetter nivået for skadepasientens rettigheter (11).

Tromsø er sentrum i en avansert, geografisk vidtfavnende prehospital tjeneste - et handlingsrettet akuttmedisinsk og kirurgisk miljø med akademisk basis. I sykehus med få store traumer vedlikeholdes mange av de kirurgiske og anestesiologiske ferdigheter gjennom behandling av andre pasientgrupper. Samhandling, gjensidige korreksjoner, diagnostikk/akuttbehandling i riktig rekkefølge og traumefysiologisk tenkemåte må også ivaretas gjennom trening med traumepasienter. Landets traumesentre må samarbeide - ved alle er det sektorer med særlig faglig tyngde. Helse Sør-Øst tar hånd om mange med alvorlige traumer. I et eventuelt formalisert samarbeid mellom traumesentrene vil muligheten for hospitering ved traumesenteret i Oslo være til stede. Samarbeidet kunne også omfatte retningslinjer for håndtering av skader som de facto nærmer seg landsfunksjonsstatus, som komplekse ansiktsskader.

\section{Rolf Hanoa}

rolf.hanoa@ulleval.no

Rolf Hanoa (f. 1944) er professor emeritus i sosialmedisin ved Universitetet i Tromsø og i helseadministrasjon ved Universitetet i Bergen. Han er spesialist i karkirurgi og overlege ved Nevrokirurgisk avdeling, Oslo universitetssykehus, Ullevål.

\section{Litteratur}

1. Dehli T, Bågenholm A, Johnsen $\mathrm{L}-\mathrm{H}$ et al. Alvorlig skadede overført til universitetssykehus. Tidsskr Nor Legeforen 2010; 130: 1455-7.

2. Wisborg T, Monsen SA, Bartnes K et al. Regionalt traumesystem for Helse Nord. Utredning. Bodø: Helse Nord RHF, 2010.

3. Røise O, Gaarder C, Hansen KS et al. Organisering av behandlingen av alvorlig skadde pasienter. Hamar: Helse Sør-Øst RHF, 2007.

4. Hanoa R, Alvsåker K. Hjerneskaderehabilitering i tidlig fase. Tidsskr Nor Legeforen 2008; 128: 66-7.

5. Wisborg T. Results of multiprofessional training of medical teams in Iraq and Norway. Doktoravhandling. Tromsø: Det medisinske fakultet, Universitetet i Tromsø, 2008.

6. Gaarder C. Trauma care and surgical trauma training with special focus on abdominal trauma. Doktoravhandling. Oslo: Det medisinske fakultet, Universitetet i Oslo, 2007.

7. Skaga NO. Quality-of-care assessment in a Norwegian trauma population. Doktoravhandling. Oslo: Det medisinske fakultet, Universitetet i Oslo, 2009.

8. Davenport RA, Tai N. West A et al. A major trauma centre is a specialty hospital not a hospital of specialities. Br J Surg 2010; 97: 109-117.

9. Høgevold HE, red. Traumemanual. Oslo: Ullevål universitetssykehus, 2006.

10. Hanoa R, Moen O, Skjelbred P. Ansiktstraumatologi. Bergen: Fagbokforlaget, 2009.

11. Hanoa R. Den multitraumatiserte pasients rettigheter. I: Høgevold HE, red. Traumemanual. Oslo: Ullevål universitetssykehus, 2006. 